\title{
PLACING A THREADED PLUG IN THE HOLE OF A LOCKING PLATE AT THE FRACTURE LEVEL CAN INCREASE THE RESISTANCE OF THE PLATE: A BIOMECHANICAL STUDY
}

\author{
Ulusoy Ragıp Gökhan, ${ }^{1}$ Bilge Ali, ${ }^{1}$ AkalınYavuz, ${ }^{2}$ Akıncı Metin, ${ }^{3}$ Ermutlu Şahin ${ }^{4}$ \\ ${ }^{1}$ Department of orthopedics and traumatology, Kafkas University, Kars, Turkey \\ ${ }^{2}$ Department of orthopedics and traumatology, \\ Bursa Yüksek İhtisas Research and Training Hospital, Bursa, Turkey \\ ${ }^{3}$ Department of orthopedics and traumatology, Ankara Numune Research and Training Hospital, Ankara, Turkey \\ ${ }^{4}$ Faculty of Veterinary, Kafkas University, Kars, Turkey
}

Primljen/Received 08. 08. 2018. god.

Abstract: Objectives: This study aimed to evaluate whether placing a threaded plug in the hole of a locking plate at the fracture level is beneficial for increasing the resistance of the plate.

Methods: This experimental study analyzed load and compression forces in sheep tibia bone models. The following groups were assessed: Group $1(n=4)$, control bone samples; Group $2(n=4)$, samples of screw plate fixation without threaded plug in the hole at the fracture level; and Group $3(n=4)$, samples of screw plate fixation with a threaded plug in the hole at the fracture level. Elastic force, bending moment, elastic compression, and rigidity were evaluated using a three-point bending test.

Results: Group 1 showed the greatest elastic force and the least amount of compression. The rigidity and elastic force were better in Group 3 than in Group 2. The mean elastic force in Group 3 was $22.4 \%$ of that in Group 1, whereas the mean elastic force in Group 2 was $19 \%$ of that in Group 1. Rigidity in Group 3 was $24.7 \%$ of that in Group 1, whereas rigidity in Group 2 was $18.3 \%$ of that in Group 1. Improved results were obtained in Group 3 when compared with Group 2.

Conclusions: Our results suggest that placing a threaded plug in the hole of the plate at the fracture level provides additional rigidity and stability by improving resistance to loading forces, but the differences were not statistically significant.

Key words: locking plate; elasticity; rigidity, threaded; plug.

\section{INTRODUCTION}

The locking compression plate allows the combination of standard plate technology and locking screws
Prihvaćen/Accepted 23. 09. 2018. god.

having angular stability along with inter-fragmentary compression, and it is contemporarily being used for fracture fixation $(1,2,3)$.

Further understanding of fracture biology and biomechanics has allowed surgeons to use better-designed implants. To restore anatomy and mechanical stability, adequate plate fixation is necessary; thus, uneventful fracture healing can be achieved (4). A plate screw system maintains functionality if the forces applied to the system do not impair stability (5). However, failure can still occur. Distribution and appropriate positioning of screws are important to avoid insufficiency of the plate. Mechanical forces may lead to disruption of the implant after reduction and fixation of the fracture $(6,7$, 8). Screws may break, and plate breakage or plastic deformation may occur. When fatigue failure occurs, it is likely to be at the level of the open hole over the fracture site $(9,10)$. Various factors, such as the quality of bone, surgical technique, and materials used, may influence the mechanical environment of the implant.

However, there is limited research in the literature, particularly on the distribution of tension and deformation associated with forces applied after fixation of a fracture with implants and on whether placement of a threaded plug in the hole of the implant at the fracture level is useful.

The aim of the present study was to evaluate if the rigidity, elastic force, bending moment, and elastic deformation are improved by placing an additional threaded plug at the fracture level. We hypothesize that all these parameters will be improved by filling the empty hole at the fracture level. 


\section{MATERIAL AND METHODS}

\section{Study Design}

This trial was carried out after receiving approval from the local ethics committee for experimental studies. The study included a total of 12 sheep tibia bones. For all the bones, soft tissue was removed, and all bones, except for control bones, were cut at the midshaft level with an electric saw. We used a standard $3.5 \mathrm{~mm}$ titanium 10-hole locking compression plate. The plate was placed and held with reduction forceps after obtaining adequate axial compression according to AO principles, and then, the plate was fixed with locking screws. The bones were randomly allocated into three groups. Group $1(n=4)$ included intact bones with no fracture or surgical intervention. In Group 2 $(n=4)$, tibial fractures were fixed with implants, but there was no threaded plug in the hole at the fracture level. In Group 3 ( $n=4)$, screw fixation of the implant was performed, and a threaded plug was placed in the hole at the

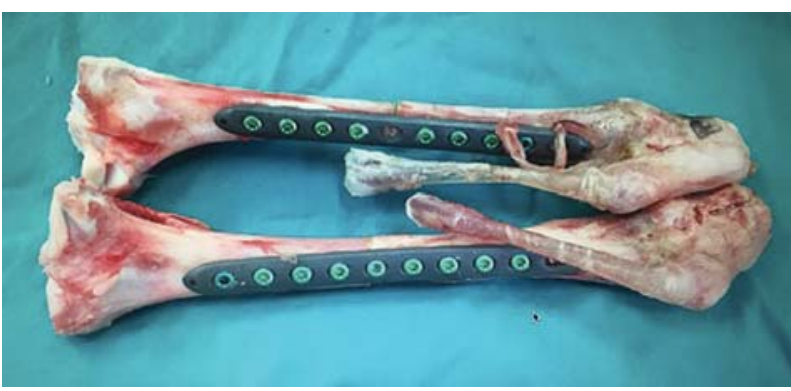

Figure 1. Tibial bone fracture after fixation with an implant devoid of a threaded plug and additional threaded plug in the hole at the level of fracture in group 2 and group 3 respectively

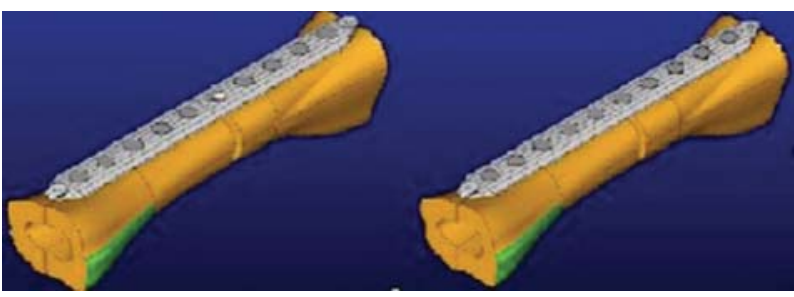

Figure 2. Three dimensional models of implant fixation in groups 2 and 3

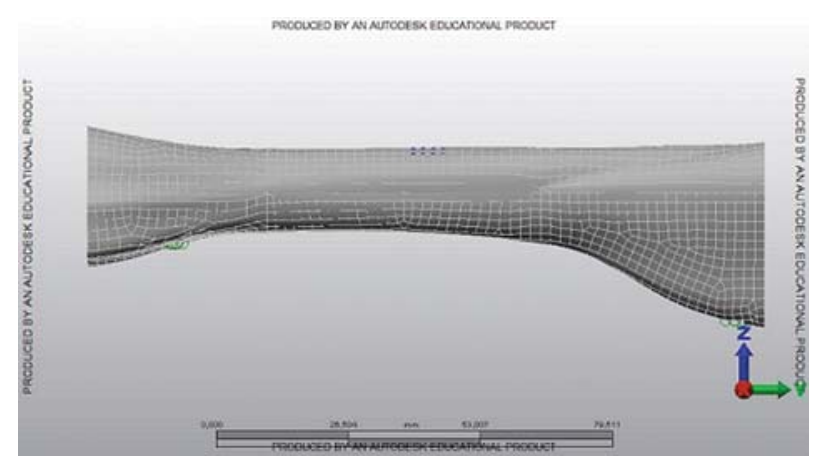

Figure 3. Finite element analysis of intact bone

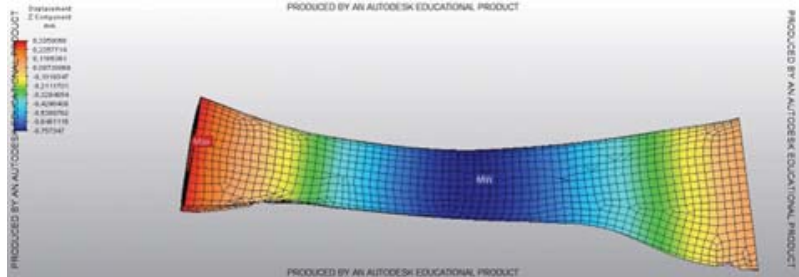

Figure 4. Evaluation of the deformation and tension of the intact bone

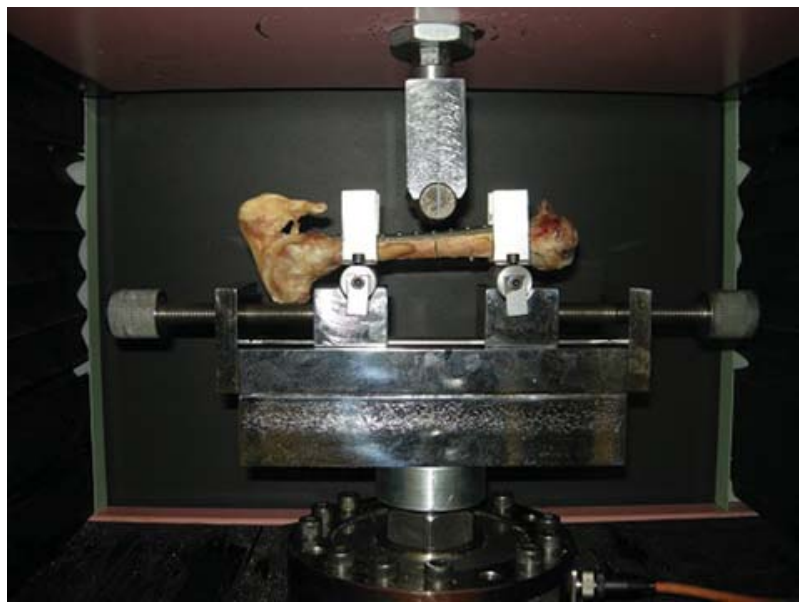

Figure 5. The three-point bending test

fracture level. The plate was on the side of force application in the three-point bending test. Figure 1 demonstrates the fixation of tibial fractures in Groups 2 and 3.

Finite element analysis (FEA) is a computerized method for predicting how a product would react to certain conditions in the real world, and it might indicate whether a product will break or work the way it was designed. The models were analyzed using Autodesk FEA software. Three-dimensional models of bones were obtained by using two-dimensional computed tomography (CT) images. Figure 2 demonstrates three-dimensional models of implant fixation in Groups 2 and 3. During analysis of the intact bone model, a force of $1224 \mathrm{~N}$ was applied, and the distance between two support points was $105 \mathrm{~mm}$. As the load employed in the experimental model for the limit of elasticity was $1224 \mathrm{~N}$, this value was selected in FEA as well. Figure 3 exhibits the FEA of a bone model in which 20,996 finite elements and 12,511 knots were used. Evaluation of the deformation and tension of the intact bone after application of $1224 \mathrm{~N}$ of force indicated compression of $0.757 \mathrm{~mm}$ (Figure 4).

Tension in the vertical axis of the bone and total equivalent tension were calculated. In the middle part of the bone, pulling tension at the lower portion and compression tension at the upper portion were 61.2 and 68.6 MPa, respectively. These values were within the elasticity limits of the bone.

Analysis of the bone fracture model was performed after fixation involving an implant and eight 
screws. The use of an additional threaded plug at the fracture level of the implant was considered to increase the resistance of the system to bending. The bone FEA model involved 79.444 finite elements (largest diameter of $1.5 \mathrm{~mm}$ ) and 36.960 knots. The implant involved 20.632 finite elements (largest diameter of $1 \mathrm{~mm}$ ) and 10,467 knots. The eight screws fixed on the implant and bone involved 5674 finite elements (largest diameter of $1 \mathrm{~mm}$ ) and 4453 knots. The threaded plug used to fix the hole involved 418 finite elements (largest diameter of $1 \mathrm{~mm}$ ) and 274 knots.

The three-point bending test (Figure 5) is a mechanical experiment used to measure Young's modulus of a material in the shape of a beam. The amount of deformation $(\delta)$ is calculated using the following formula:

$$
\delta=\frac{P L^{3}}{48 E I}
$$

where $\mathrm{P}$ indicates the amount of force employed, $\mathrm{L}$ indicates the distance between two support points, and EI indicates the rigidity of the sample. Substances with high rigidity have small $\delta$ values, whereas those with low rigidity have large $\delta$ values. As $\mathrm{P}$ and $\delta$ values can be measured during testing, EI can be calculated using the following formula:

$$
E I=\frac{P L^{3}}{48 \delta}
$$

The EI value is important for evaluating the mechanical and physical behaviors of materials.
Results obtained after the experiments are presented in Table 1.

\section{Statistical Analysis}

All statistical analyses were performed using commercially available software (Statistical Package for Social Sciences, version 23, (IBM Corp., Armonk, NY, USA.) with $95 \%$ confidence intervals. One-way analysis of variance (ANOVA) and Tukey tests were used to compare differences among groups.

\section{RESULTS}

We found that the greatest rigidity and elastic force in conjunction with the lowest amount of deformation were in Group 1 (control group). Elasticity and rigidity were better in Group 3 than in Group 2, and deformation was less obvious in Group 3. The mean elastic force in Group 3 was $22.4 \%$ of that in Group 1, whereas the mean elastic force in Group 2 was $19 \%$ of that in Group 1. Similarly, the rigidity in Group 3 was $24.7 \%$ of that in Group 1, whereas the rigidity in Group 2 was $18.3 \%$ of that in Group 1. In other words, placement of an additional threaded plug at the fracture level appeared to improve stabilization; however, the difference between Groups 2 and 3 was not statistically significant.

Analysis of the situation without a threaded plug placed in the hole at the fracture level revealed a defor-

\begin{tabular}{|c|c|c|c|c|c|}
\hline Group & Sample \# & $\begin{array}{l}\text { Elastic force } \\
(\mathbf{N})\end{array}$ & $\begin{array}{l}\text { Bending moment } \\
\text { (Nmm) }\end{array}$ & $\begin{array}{c}\text { Elastic deformation } \\
(\mathrm{mm})\end{array}$ & $\begin{array}{l}\text { Rigidity } \\
\left(\mathrm{Nmm}^{2}\right)\end{array}$ \\
\hline \multirow[t]{5}{*}{1} & I & 1236.06 & 32446.58 & 4.245 & $7.15 \mathrm{E}+06$ \\
\hline & II & 1245.87 & 32704.09 & 2.989 & $1.04 \mathrm{E}+07$ \\
\hline & III & 1265.49 & 33219.11 & 6.244 & $6.03 E+06$ \\
\hline & IV & 1147.77 & 30128.96 & 3.933 & $7.52 \mathrm{E}+06$ \\
\hline & Average & 1223.80 & 32124.68 & 4.353 & $7.78 \mathrm{E}+06$ \\
\hline \multirow[t]{5}{*}{2} & I & 215.82 & 5665.28 & 5.670 & $8,65 \mathrm{E}+05$ \\
\hline & II & 235.44 & 6180.30 & 4.690 & $1.67 \mathrm{E}+06$ \\
\hline & III & 245.25 & 6437.81 & 8.066 & $8.49 \mathrm{E}+05$ \\
\hline & IV & 235.44 & 6180.30 & 3.407 & $2.33 \mathrm{E}+06$ \\
\hline & Average & 232.99 & 6115.92 & 5.458 & $1.43 \mathrm{E}+06$ \\
\hline \multirow[t]{5}{*}{3} & I & 264.87 & 6952.84 & 4.873 & $2.47 \mathrm{E}+06$ \\
\hline & II & 294.3 & 7725.38 & 5.141 & $1.64 \mathrm{E}+06$ \\
\hline & III & 294.3 & 7725.38 & 4.040 & $2.43 \mathrm{E}+06$ \\
\hline & IV & 245.25 & 6437.81 & 4.802 & $1.15 \mathrm{E}+06$ \\
\hline & Average & 274.68 & 7210.35 & 4.714 & $1.92 \mathrm{E}+06$ \\
\hline
\end{tabular}

Table 1. Results of elastic force, bending moment, elastic deformation and rigidity in 3 experimental groups

$\mathbf{N}$ : Newton, Nmm: Newton millimeter, $\mathbf{m m}$ : millimeter, $\mathbf{N m m}^{2}$ : Newton millimetersquare 
mation of $1.65 \mathrm{~mm}$ in the vertical axis. Moreover, tension values detected in the pulling and compression axes were 888 and $1106 \mathrm{MPa}$, respectively. Tension was most prominent at the fracture level where the hole of the implant was empty.

In the bone implant model with a threaded plug placed in the hole of the implant at the fracture level, a force of $724 \mathrm{~N}$ was administered at the plug with a distance of $105 \mathrm{~mm}$ between support points. The greatest deformation in the vertical plane was $1.163 \mathrm{~mm}$, and the greatest amount of tension measured at the implant for pulling and compression were 599 and $795 \mathrm{MPa}$, respectively.

The intact bone in Group 1 showed the highest resistance. Although the force applied in this group was higher than the forces applied in Groups 2 and 3, deformation and tension were lower. The same amount of force (724 N) was applied in Groups 2 and 3. Deformation in the vertical axis was less obvious, and tension at the upper and lower surfaces of the implant was reduced in Group 3.

With regard to elastic force, ANOVA showed a significant difference between the tested groups $(p<$ $0.05)$. The mean elastic force was 1223.80 in Group 1 , 232.99 in Group 2, and 274.68 in Group 3. The Tukey test showed significant differences between Group 1 and Groups 2 and $3(p<0.05)$. However, the difference between Groups 2 and 3 was not significant (Table 2).

The mean bending moment was 32,124.68 in Group 1, 6115.92 in Group 2, and 7210 in Group 3. ANOVA showed significant differences between the groups $(p<0.05)$. The Tukey test showed significant differen- ces between Group 1 and Groups 2 and $3(p<0.05)$. However, the difference between Groups 2 and 3 was not significant (Table 3).

Although Group 1 showed the greatest rigidity and lowest deformation, there were no statistically significant differences according to ANOVA and Tukey tests $(p>0.05)$.

\section{DISCUSSION}

The present experimental study attempted to determine whether placement of an additional threaded plug at the fracture level could alter the biomechanics and resistance of the system in a sheep tibia model. We found that placement of a threaded plug in the hole at the fracture level improved the rigidity of the system and increased resistance to external impacts. Results obtained in Group 3 were better than those obtained in Group 2; however, the differences were not statistically significant. The data were confirmed in a finite element model of the tibia where generated and mechanical effects of loading forces were evaluated.

Following placement of the implant, the process of healing, which leads to osteogenesis in the surrounding region of the implant surface, starts. After installation of the implant, implant stability depends only on mechanical contact between the surrounding bone tissue and the implant. During successful healing, new bone formation facilitates implant stability over time, and the degree of initial implant stability (resistance to micromotion) is influenced by the implant design and its relation to the preparation for osteotomy. Micromo-

Table 2. Comparison of the groups according to Tukey test with regard to elastic force

\begin{tabular}{|l|c|c|c|c|}
\hline \multicolumn{2}{|c|}{} & Average difference & p \\
\hline \multirow{3}{*}{ Elastic Force (N) } & \multirow{3}{*}{ Group 1 } & Group 2 & $990,81000^{*}$ & $\mathbf{0 , 0 0 0}$ \\
\cline { 3 - 5 } & & Group 3 & $949,11800^{*}$ & $\mathbf{0 , 0 0 0}$ \\
\cline { 3 - 5 } & \multirow{3}{*}{ Group 2 } & Group 1 & $-990,81000^{*}$ & $\mathbf{0 , 0 0 0}$ \\
\cline { 3 - 5 } & & Group 3 & $-41,69200$ & $\mathbf{0 , 1 0 3}$ \\
\cline { 3 - 5 } & \multirow{3}{*}{ Group 3 } & Group 1 & $-949,11800^{*}$ & $\mathbf{0 , 0 0 0}$ \\
\cline { 3 - 5 } & & Group 2 & 41,69200 & $\mathbf{0 , 1 0 3}$ \\
\hline
\end{tabular}

Table 3. Comparison of the groups according to Tukey test with regard to bending moment

\begin{tabular}{|l|c|c|c|c|}
\hline \multicolumn{2}{|c|}{} & Average difference & p \\
\hline \multirow{3}{*}{ Bending Moment (Nmm) } & \multirow{3}{*}{ Grup 1 } & Grup 2 & $26008,76200^{*}$ & $\mathbf{0 , 0 0 0}$ \\
\cline { 3 - 5 } & & Grup 3 & $24914,33200^{*}$ & $\mathbf{0 , 0 0 0}$ \\
\cline { 3 - 5 } & \multirow{3}{*}{ Grup 2 } & Grup 1 & $-26008,76200^{*}$ & $\mathbf{0 , 0 0 0}$ \\
\cline { 3 - 5 } & & Grup 3 & $-1094,43000$ & $\mathbf{0 , 1 0 3}$ \\
\cline { 3 - 5 } & \multirow{2}{*}{ Grup 3 } & Grup 1 & $-24914,33200^{*}$ & $\mathbf{0 , 0 0 0}$ \\
\cline { 3 - 5 } & & Grup 2 & 1094,43000 & $\mathbf{0 , 1 0 3}$ \\
\hline
\end{tabular}


tion of the implant may cause interfacial deformation of tissue, which can subsequently affect the type of tissue formed. Therefore, it is important to achieve sufficient implant stability for osteointegration (11).

The mechanical loading of bone may positively influence bone mass by facilitating bone formation over bone resorption. It may increase bone mineral density and improve trabecular and cortical microarchitecture that contribute to bone strength (12). The interaction of various factors plays a role in the stabilization of the fracture and maintenance of appropriate physical and mechanical conditions after fixation (13).

The presence of an open hole in the load-bearing region of the plate results in stress concentration. To evaluate the effects of placing a threaded plug in the empty hole of a locking one-third tubular plate, Bellapianta et al. conducted FEA and then tested four different plate configurations at physiologically relevant loads experimentally using synthetic bone models. In their study, they found that the stress concentration factor reduced to 1.0 , with reduction in stress to a level comparable to that with a solid plate (no hole) (14).

In another study, 20 five-hole tubular locking plates were mounted on an oak dowel with a $1 \mathrm{~cm}$ gap, and it was found that addition of screw-hole inserts did not change the biomechanical properties of the plate in a meaningful way (15). However, this was a simple study, and plate bending was not tested.

In a segmental defect model, Tompkins et al. tested the fatigue life of four constructs using an eight-hole locking plate. In their study, locking screws did not improve fatigue life; however, a locking button increased the fatigue life of the locking plate (16).

In this current study, we used fresh sheep tibia bones, which were randomly allocated into three groups, and created a transverse fracture without a gap. The same implant design was used in this trial, but two different fixation methods and a control group were utilized. In our opinion, the weakness is evaluation of the effect of the threaded plug in distraction. Further research is necessary to demonstrate the effects of this approach in different applications.

The present study provides new insights on the biomechanics and interaction of forces in a sheep tibia model. Realistic representation of deformation and tension on exposure to forces with different implant fixation techniques provides useful data for circumstances in physiological conditions. We found that placement of an additional threaded plug at the fracture level can be beneficial for stabilization and resistance.

The present study had some limitations, including a small sample size and experimental design. On the other hand, one of the major strengths was the use of FEA that allowed assessment of whether a threaded plug could alter the mechanical resistance of an implant. However, during interpretation of our results, it should be noted that in orthopedic biomechanics, FEA is considered a comparative tool rather than a predictive measure.

\section{CONCLUSION}

The results of the present study suggest that placement of a threaded plug in the hole of an implant at the fracture level might provide additional rigidity and stability by improving resistance to loading forces. However, the benefit might not be significant. Further controlled trials with a larger series are required to further assess the present results.
Abbreviations
FEA - Finite Element Analaysis
CT - Computed tomography

\section{Declarations}

\section{Ethics approval and consent to participate}

Not applicable

\section{Availability of data and material}

The datasets used and/or analysed during this study are available from the corresponding author on reasonable request.

\section{Competing interests}

The authors declare that they have no competing interests

\section{Authors' contributions}

GRU: Conception of the study, Collecting the data, Writing the manuscript, Editing the manuscript.

AB: Collecting the data, Editing the manuscript

YA: Collecting the data, Reviewing the manuscript

MA: Conception of the study, Supervising the study, Editing the manuscript

ŞE: Collecting the data, Editing the manuscript

\section{Acknowledgement}

We thank to Prof. Re \}at Özcan for interpretation of mechanical analysis

\section{Licensing}

This work is licensed under a Creative Commons Attribution 4.0 International (CC BY 4.0) License. 


\title{
Sažetak
}

\section{UGRAĐIVANJE NAVOJNOG ŠRAFA U OTVOR ZAKLJUČAVAJUĆE PLOČE NA MESTU PRELOMA MOŽE POVEĆATI ČVRSTINU PLOČE NA OPTEREĆENJA: BIOMEHANIČKA STUDIJA}

\author{
Ulusoy Ragıp Gökhan, ${ }^{1}$ Bilge Ali, ${ }^{1}$ Akalın Yavuz, ${ }^{2}$ Akıncı Metin, ${ }^{3}$ Ermutlu Şahin ${ }^{4}$ \\ ${ }^{1}$ Department of orthopedics and traumatology, Kafkas University, Kars, Turkey \\ 2 Department of orthopedics and traumatology, Bursa Yüksek İhtisas Research and Training Hospital, Bursa, Turkey \\ ${ }^{3}$ Department of orthopedics and traumatology, Ankara Numune Research and Training Hospital, Ankara, Turkey \\ ${ }^{4}$ Faculty of Veterinary, Kafkas University, Kars, Turkey
}

Cilj: Cilj ove studije bio je da se proceni kolika je korisnost ugradnje navojnog šrafa u otvor zaključavajuće na mestu preloma kod povećanog otpora istog.

Metode: Ova ekperimentalna studija analizirala je teret i kompresionu silu tibijalne kosti kod ove. Sledeće grupe su posmatrane: Grupa $1(n=4)$, kontrolni uzorci kosti; Grupa $2(n=4)$, uzorci prelomljene kosti bez uvijenog šrafa u otvoru na mestu preloma; i Grupa $3(n=4)$ činili su uzorci prelomljene kosti u koji je bio ugrađen navijeni šraf u otvor na mestu preloma. Elastična sila, mogućnost savijanja, elastična kompresija i rigidnost bili su procenjivani koristeći three-point bending test.

Rezultati: Grupa 1 pokazala je najveći stepen elastične sile i najmanji stepen kompresije. Rigidnost i si-

\section{REFERENCES}

1. Nassiri M, Macdonald B, O’Byrne JM. Computational modelling of long bone fractures fixed with locking plates-How can the risk of implant failure be reduced? J Orthop. 2013; 10(1): 29-37.

2. Niemeyer P, Südkamp NP. Principles and clinical application of the locking compression plate (LCP). Acta Chir Orthop Traumatol Cech. 2006; 73(4): 221-8.

3. Hebert-Davies J, Laflamme GY, Rouleau D, Canet F, Sandman E, Li A, et al. A biomechanical study comparing polyaxial locking screw mechanisms. Injury. 2013; 44(10): 1358-62.

4. Gardner MJ, Evans JM, Dunbar RP. Failure of fracture plate fixation. J Am Acad Orthop Surg. 2009; 17(10): 647-57.

5. Perren SM, Russenberger M, Steinemann S, Müller ME, Allgöwer M. A dynamic compression plate. Acta Orthop Scand Suppl. 1969; 125: 31-41.

6. Kanchanomai C, Phiphobmongkol V, Muanjan P. Fatigue failure of an orthopedic implant-A locking compression plate. Eng Fail Anal. 2008; 15(5): 521-30.

7. Wagner M. General principles for the clinical use of the LCP. Injury. 2003; 34(Suppl 2): B31-42.

8. Marcomini JB, Baptista CA, Pascon JP, Teixeira RL, Reis FP. Investigation of a fatigue failure in a stainless steel femoral plate. J Mech Behav Biomed Mater. 2014; 38:52-8. la elastičnosti bile su bolje u Grupi 3 u odnosu na grupu 2. Srednja vrednost elastične sile u Grupi 3 iznosila je $22,4 \%$ one procenjene u Grupi 1 , dok je srednja vrednost elastične sile u Grupi 2 bila $19 \%$ od one procenje $u$ Grupi 1. Rigidnost u Grupi 3 iznosila je $24,7 \%$ od one vrednosti procenjene u Grupi 1, dok je rigidnost u Grupi 2 bila 18,3\% od one u Grupi 1. Bolji rezultati nađeni su u Grupi 3 kada smo ih uporedili saGrupom 2.

Zaključak: Naši rezultati sugerišu da ugradnja navijenog šrafa u otvor na mestu preloma omogućava dodatnu rigidnost i stabilnost, time što pojačava otpor na mestu sile, ali razlike nisu pokazale statističku značajnost.

Ključne reči: locking plate, elastičnost, rigidnost, navoj, šraf.

9. Sommer C, Babst R, Müller M, Hanson B. Locking compression plate loosening and plate breakage: a report of four cases. J Orthop Trauma. 2004; 18(8): 571-7.

10. Gere JM, Timoshenko SP. Stress concentrations. In: Gere JM, Timoshenko SP, eds. Mechanics of Materials, $3^{\text {rd }}$ ed. Boston: PWS; 1990: 119-25.

11. Halldin A, Jinno Y, Galli S, Ander M, Jacobsson M, Jimbo R. Implant stability and bone remodeling up to 84 days of implantation with an initial static strain. An in vivo and theoretical investigation. Clin Oral Implants Res. 2016; 27(10): 1310-16.

12. Zacchetti G, Wiskott A, Cugnoni J, Botsis J, Ammann P. External mechanical microstimuli modulate the osseointegration of titanium implants in rat tibiae. Biomed Res Int. 2013; 2013: 234093.

13. Piccinini M, Cugnoni J, Botsis J, Ammann P, Wiskott A. Influence of gait loads on implant integration in rat tibiae: experimental and numerical analysis. J Biomech. 2014; 47(13): 3255-63.

14. Bellapianta J, Dow K, Pallotta NA, Hospodar PP, Uh RL, Ledet EH. Threaded screw head inserts improve locking plate biomechanical properties. J Orthop Trauma. 2011; 25(2): 65-71.

15. Eichinger JK, Herzog JP, Arrington ED. Analysis of the mechanical properties of locking plates with and without screw hole inserts. Orthopedics. 2011; 34(1): 19.

16. Tompkins M, Paller DJ, Moore DC, Crisco JJ, Terek RM. Locking buttons increase fatigue life of locking plates in a segmental bone defect model. Clin Orthop Relat Res. 2013; 471(3): 1039-44.

\author{
Correspondence to/Autor za korespondenciju \\ Gökhan R Ulusoy, MD \\ Department of Orthopedics and Traumatology, Kafkas University, Kars, Turkey \\ E-mail: ulusoyg@hotmail.com \\ Phone: +90 5454575773
}

Fax: +90 4742251195 